\title{
Investigations on the potential of woodlice as bioindicators of grassland habitat quality
}

\author{
C. Souty-Grosset $^{\mathrm{a}, *}$, I. Badenhausser ${ }^{\mathrm{b}}$, J.D. Reynolds ${ }^{\mathrm{c}}$, A. Morel ${ }^{\mathrm{a}, \mathrm{b}}$ \\ " Université de Poitiers UMR CNRS 6556 "Génétique et Biologie des Populations de Crustacés", 40, \\ avenue du Recteur-Pineau, 86022 Poitiers cedex, France \\ b Inra, Laboratoire de Zoologie, 86600 Lusignan, France \\ c Department of Zoology, University of Dublin, Trinity College, Dublin 2, Ireland
}

Available online 18 October 2005

\begin{abstract}
As intensive land-use practices may reduce available leaf litter, woodlice-important decomposers of leaf litter - may show a loss of biomass and a decrease in number of species. Their diversity as grassland detritivores could thus be a potential guide to ecosystem activity in natural and cultivated grasslands. Woodlice diversity was studied in different grassland types at three sites in Western France: Avon, with semi-natural grasslands; Fors, with mixed farming; Lusignan, with intensive farming. Woodlice were collected by hand in plot centres, borders and field boundaries. Isopod numbers were higher at Fors than at Lusignan; species assemblages were dominated by Philoscia muscorum at Lusignan whereas this species is less numerous at Fors than Armadillidium vulgare and Armadillidium nasatum. These results also differ with grassland type, with higher species diversity or number of individuals in temporary and permanent grasslands at Fors. Hedges were important in increasing isopod diversity within plots. Assemblages reflect grassland quality with high densities and diversity of woodlice in the permanent grasslands at Avon.

(C) 2005 Elsevier SAS. All rights reserved.
\end{abstract}

Keywords: Ecology; Bioindicators; Terrestrial isopods; Agriculture; Environment

\section{Introduction}

Soil detritivores, making up the largest biomass of grasslands invertebrates, have a particularly important ecosystem function in mineralising organic matter [3]. They transform litter into faecal pellets which decompose rapidly. For example, terrestrial isopods utilise more than $10 \%$ of the annual litter, increasing fourfold the surface available to micro-organisms $[9,12,14]$.

It has been observed that the specific diversity and abundance of terrestrial isopods decrease in intensive agricultural systems, with particularly marked differences between organically managed and more conven-

\footnotetext{
* Corresponding author.

E-mail address: catherine.souty@univ-poitiers.fr (C. Souty-Grosset).
}

tional plots [17]. Herbicide application leads both to increased mortality and lowered fecundity [17]. These products reduce available food and can change soil $\mathrm{pH}$, an important parameter for isopods [22].

Landscape modifications include enlargement of fields to make them amenable to mechanisation. Such increases in plot size may entail habitat fragmentation through disruption of continuous structures (verges, hedges, lanes) which permit species to survive. Hedgerows, for example, are important for biodiversity because a large number of species use them as refuges or conduits to more optimal habitats [16]. Increased isopod mortality was observed in habitats where the structure had been simplified, without refuge zones [6].

Agricultural practices in these perennial habitats will affect these arthropods. Actions such as cutting or graz- 
ing lead to reduction in vegetation height and biomass and a partial or total destruction of litter, affecting the entire community [15,3]. Cutting is a non-selective method of grassland management compared with grazing. Removal of forage will reduce available litter for soil decomposers [18]. Grazing brings other effects in addition to those common to both methods of exploitation. Depending on the herbivores present (cattle, sheep or horses), defoliation is generally selective, with different impacts on the invertebrate fauna. Trampling by herbivores causes not only disturbance of arthropods [15] but also a reduction in soil coverage by plants [3]. Isopods are sensitive to botanical composition, both for food [19] and through vegetation structure [4]. Invertebrates respond to different levels of nitrogen in plants. In general, an increase in nitrogen levels is correlated with a decrease in biodiversity [15]. Nevertheless, whether managed by intensive pasturing or by cutting, grasslands are less disturbed than by annual cultivation, and the annual cycle of numerous arthropod species can take place because of the rarity of ploughing, which is the biggest disturbance.

The generally mild climate of Atlantic Europe permits the survival of a range of isopod species which include generalists, specialists and edge-of-range rarities $[23,24]$. As the climax vegetation in most Atlantic habitats is woodland, natural grasslands are relatively few. Most studies of detritivores have been conducted on woodland sites, where autumnal accumulation of leaf litter is pronounced. Agriculture is increasingly dominated by pastures, but their nature has changed markedly in recent years, with a tendency towards reseeding and intensification on the better soils, and reduction of grazing or abandonment in more marginal habitats. Intensive land-use practices reduce the available litter [1] and pollution will also reduce microbial activity, and thus both processes may reduce the invertebrate detritivore biomass, leading to a loss in biodiversity.

This foundation study, conducted at sites in Western France (Poitou-Charentes), sought to extend investigations of decomposition to semi-natural and managed grasslands, as an important vegetational/land-use category in these regions. It aimed to look at the abundance and diversity of isopods as a potential guide to ecosystem activity in natural and improved grasslands, and to relate this to their importance and conservation value. This involved determining the species present, their relative abundance and the influence of landscape structural elements on isopod community structure in fields.

\section{Materials and methods}

The study first set out to establish relative diversity and abundance of different woodlouse species in grassland fields and in the connecting elements of the landscape in spring. Observations were made at three sites in the Poitou-Charentes Region (Fig. 1): a Natura 2000 site at Avon (Deux Sèvres), the experimental base for INRA at Lusignan (Vienne) and the Fors sector (Deux Sèvres), which is also used by Inra and Cnrs at Chizé to study the impact of agricultural practices on biodiversity [2]. At Lusignan, the nature of the soils and history of crop rotations are known. At Fors, the fields have been mapped using GIS and have been the subject of major studies since 1994, involving crop rotations, and entomological and ornithological observations [2]. Preliminary results in 2003 indicate that the three selected sites are contrasting in both soil type and agricultural grasslands. Avon is semi-natural, Lusignan has experienced intensive practices over many years, whereas Fors is in a zone of mixed farming, with a more recent history of intensification. Different types of grasslands were studied (Table 1); artificial, temporary and permanent as defined in agricultural statistics by the Ministry of Agriculture, Fisheries and Food [11]. 'Artificial grasslands' are those established for less than 5 years and sown exclusively with leguminous fodder crops (alfalfa, clover). Temporary grasslands are similarly less than 5 years old sown with fodder grasses, pure or mixed with leguminous plants. Permanent grasslands are composed of hardy herbaceous fodder plants; they comprise both fields sown for a long time (6-10 years) and natural grasslands, not reseeded.

At both farmland sites plots were chosen using a map of crop types for 2003 in conjunction with their morphological characteristics and accessibility. Each plot was subdivided into a central zone, the borders and the boundaries or connections. The outer five metres of cultivation were considered as the borders, each corresponding to a different connection. Between three and five individuals searched each plot and its borders and connections, and woodlouse were hand collected over a total cumulated period of about 1 hour. At the three sites hand collecting was made in April. Except in Avon, collecting was carried out separately in connections, borders and plots. During collecting, the type of soil (sandy, clayey), the quantity of stones, the degree of cloudiness and the plant species present were noted. The proportion of bare soil and height of vegetation were also recorded for each sub-plot, as were any human activities (cutting, silage, fertilisation etc.). As in Hornung and Warburg [10], the Shannon-Wiener for- 


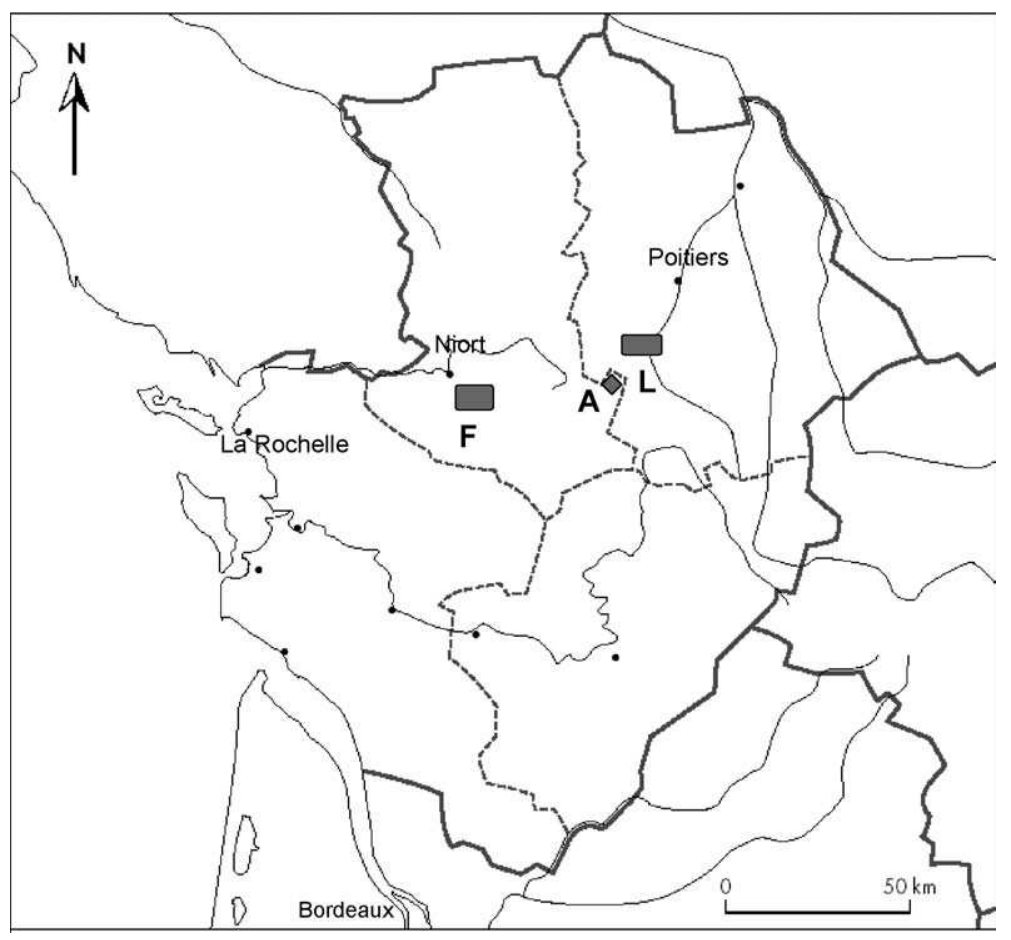

Fig. 1. Location of the three sampled sites in Poitou-Charentes: L (Lusignan, Vienne), A (Avon, Deux Sèvres), F (Fors, Deux Sèvres).

mula was used for species diversity $H^{\prime}=-\sum_{i=1}^{S}\left[\frac{n_{i}}{N} \times \operatorname{Ln} \frac{n_{i}}{N}\right], n_{i}$ meaning the number of individuals of the species $i$ in the sample of $N$ individuals.

\section{Results}

Seven woodlouse species belonging to four families were encountered in the grasslands examined. Clear differences were seen between study sites both for species diversity and abundance (Tables 2 and 3), and for the different types of grasslands (Fig. 2).

The species were differentially represented at the three sites. Oniscus asellus was absent from plots, borders and connections at Fors, while it was found at Avon and Lusignan. At Lusignan, Armadillidium vulgare and Armadillidium nasatum were rarely found, while at Avon and Fors, they were common. At Lusignan, six different species were encountered (Table 2). In every habitat Philoscia muscorum was the most common species. O. asellus and Porcellionides cingen$d u s$ were found together in alfalfa, while A. nasatum occurred in permanent grasslands. These relative differences should be treated with caution due to the small numbers collected. Shannon indices calculated for each plot (plot + borders and connections) ranged from 0 (only one species) to 1.17 and variability between plots was high (Table 4). At Fors, five species were found but three species were commonly encountered in the plots (Table 2): P. muscorum, A. nasatum and A. vulgare. Shannon indices ranged from 0.18 to 1.09 , and are not very different between grassland types (Table 4). At Avon, five species were found in each grassland and Shannon indices were higher compared to $\mathrm{Lu}-$ signan (Table 4).

The total numbers of isopods in plots, their borders and connections (Table 3 and Fig. 2) were clearly lower at Lusignan (16.3 woodlice per plot), compared to Avon ( 88 woodlice per plot) and Fors (122.6 woodlice per plot), whatever the grassland type. Although the hand-search method cannot be completely standardised, it reflects woodlouse abundance to a certain degree. More woodlice were captured in the connections than in the plot and its borders (Table 3). Whatever the site, densities were lower in the centre of the plots than in the borders or in the connections.

At Lusignan, mean number of woodlice per plot was nil, for borders it was five individuals (S.E. $=3.5$ ) and for connections it was $11.3 \pm 4.9$ (S.E.) (Table 3). Eighty-five percent of the captured individuals came from a single plot of alfalfa, while seven other plots (two of cocksfoot, the rest being temporary or permanent grasslands sown with rye-grass, of which four were pastured) yielded no woodlice (Fig. 2). 
Table 1

Plots studied in Fors, Lusignan and Avon

\begin{tabular}{|c|c|c|c|c|}
\hline Plots & Lambert II coordinates $(x ; y)$ & Cultivation & Age (years) & Area (ha) \\
\hline Fors & $388255 ; 2143404$ & Clover & 1 & 4.00 \\
\hline Fors & $392471 ; 2138371$ & Clover & $?$ & 1.63 \\
\hline Fors & $390823 ; 2142174$ & Alfafa & 1 & 1.13 \\
\hline Fors & $389555 ; 2139258$ & Alfafa & 1 & 2.03 \\
\hline Fors & $387208 ; 2139406$ & Alfafa & 3 & 8.22 \\
\hline Fors & $388862 ; 2139877$ & Alfafa & $?$ & 1.45 \\
\hline Fors & $390764 ; 2139278$ & Alfafa & $>3$ & 1.89 \\
\hline Fors & $391333 ; 2139985$ & Alfafa & $>3$ & 2.35 \\
\hline Fors & $389428 ; 2140096$ & Temporary grassland. & 1 & 3.96 \\
\hline Fors & $389416 ; 2142889$ & Temporary grassland & 1 & 2.00 \\
\hline Fors & $389411 ; 2139743$ & Temporary grassland & $2-3$ & 3.36 \\
\hline Fors & $389615 ; 2142641$ & Temporary grassland. & $2-3$ & 1.07 \\
\hline Fors & $388732 ; 2142824$ & Permanent grassland. & $>3$ & 2.50 \\
\hline Fors & $386268 ; 2139017$ & Permanent grassland & $>3$ & 2.74 \\
\hline Fors & $386124 ; 2139073$ & Permanent grassland & $>3$ & 1.62 \\
\hline Fors & $392181 ; 2138237$ & Permanent grassland & $>3$ & 0.70 \\
\hline Lusignan & Le Petit Pin & Alfafa & 3 & 8.01 \\
\hline Lusignan & La pétinière & Alfafa & 1 & 5.56 \\
\hline Lusignan & Le Chêne & Cocksfoot grass & 1 & 2.20 \\
\hline Lusignan & La pétinière & Cocksfoot grass & 1 & 1.86 \\
\hline Lusignan & Le petit pin (Le milieu) & Temporary grassland & $2-3$ & 4.72 \\
\hline Lusignan & Le petit pin (Les pommiers) & Temporary grassland & $2-3$ & 4.40 \\
\hline Lusignan & Les Verrines A & Permanent grassland & $5-6$ & 3.79 \\
\hline Lusignan & Les Verrines B & Permanent grassland & $2-3$ & 3.71 \\
\hline Lusignan & Les Verrines $\mathrm{C}$ & Permanent grassland & $4-5$ & 8.92 \\
\hline Lusignan & Les Verrines Y & Permanent grassland & $5-6$ & 2.31 \\
\hline Lusignan & La pétinière & Permanent grassland & $>8$ & 1.11 \\
\hline Lusignan & La gralière & Permanent grassland & $>8$ & 0.61 \\
\hline Lusignan & La gralière & Permanent grassland & 1 & 2.50 \\
\hline Avon & Pie Morin & Permanent grassland & $>10$ & 3.50 \\
\hline
\end{tabular}

Table 2

Relative abundance of species in grassland plots at Avon (plot + borders + connections), Lusignan and Fors (plot and borders)

\begin{tabular}{|c|c|c|c|c|c|c|c|c|}
\hline & \multicolumn{2}{|c|}{ Alfalfa } & \multirow{2}{*}{$\begin{array}{l}\text { Clover } \\
\text { Fors }\end{array}$} & \multicolumn{2}{|c|}{$<3$ year grassland } & \multicolumn{2}{|c|}{$>3$ year grassland } & \multirow[b]{2}{*}{ Avon } \\
\hline & Lusignan & Fors & & Lusignan & Fors & Lusignan & Fors & \\
\hline A. vulgare & 0 & 0.33 & 0 & 0 & 0.17 & 0 & 0.24 & 0.25 \\
\hline A. nasatum & 0 & 0.13 & 0.10 & 0 & 0.53 & 0.08 & 0.33 & 0.42 \\
\hline P. muscorum & 0.84 & 0.54 & 0.90 & 1 & 0.30 & 0.92 & 0.43 & 0.23 \\
\hline O. asellus & 0.02 & 0 & 0 & 0 & 0 & 0 & 0 & 0.01 \\
\hline P. scaber & 0 & 0 & 0 & 0 & 0 & 0 & 0 & 0 \\
\hline$P$. cingendus & 0.14 & 0 & 0 & 0 & 0 & 0 & $<0.01$ & 0 \\
\hline P. hofmanseggi & 0 & 0 & 0 & 0 & 0 & 0 & 0 & 0.09 \\
\hline
\end{tabular}

At Fors, woodlice density in the centre of the plot was different according to the type of grassland but it was lower $(9 \pm 3.5$ woodlice per plot) than that in the borders $(41.7 \pm 12.1$ individuals per plot borders $)$ and in the connections $(71.8 \pm 14.8$ woodlice per plot connections) (Table 3). Artificial grasslands (clover, alfalfa) were in general less rich in woodlice than temporary or permanent grasslands. However, there were again 
Table 3

Mean number of woodlice individuals per plot, borders, connections, and total numbers at Lusignan, Fors and Avon for different types of grassland. Standard errors are given in parentheses

\begin{tabular}{|c|c|c|c|c|c|c|c|c|}
\hline & \multicolumn{2}{|c|}{ Alfalfa } & \multirow{2}{*}{$\begin{array}{l}\text { Clover } \\
\text { Fors }\end{array}$} & \multicolumn{2}{|c|}{$<3$ year grassland } & \multicolumn{2}{|c|}{$>3$ year grassland } & \multirow[b]{2}{*}{ Avon } \\
\hline & Lusignan & Fors & & Lusignan & Fors & Lusignan & Fors & \\
\hline Plot & 0 & $1.2(1.2)$ & $2.5(2.5)$ & 0 & $19(8.9)$ & 0 & $14(9)$ & - \\
\hline Borders & $22.5(20.5)$ & $3.8(2.7)$ & $21(17)$ & $0.6(0.6)$ & $68.2(26.2)$ & $2.4(1.6)$ & $82.2(25.2)$ & - \\
\hline Connections & 44 (14) & $34.8(9.3)$ & $52(24)$ & $2.8(1.7)$ & 109.5 (26.9) & $6.8(2.3)$ & $99.7(43.5)$ & - \\
\hline Total & $66.5(34.5)$ & $39.8(10.2)$ & $75.5(44)$ & $3.4(2.2)$ & $196.7(52.8)$ & $3.4(2.2)$ & $196(66.5)$ & $88(3)$ \\
\hline Number of plots & 2 & 6 & 2 & 5 & 4 & 5 & 4 & 2 \\
\hline
\end{tabular}

Lusignan

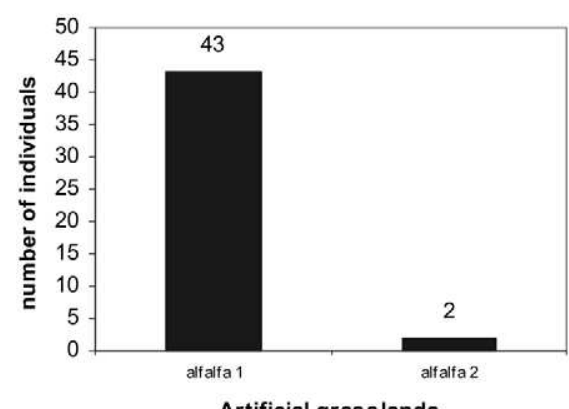

Artificial grasslands

Lusignan

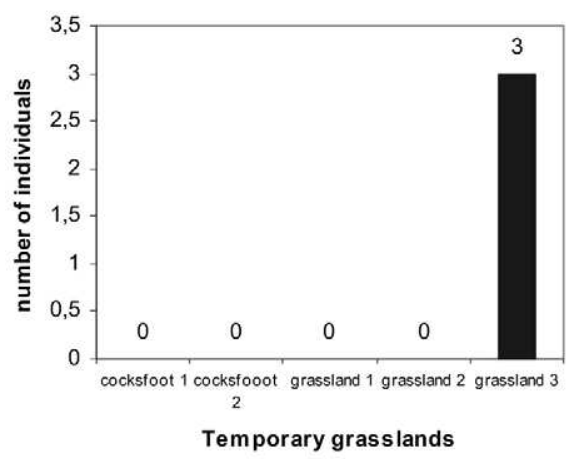

Lusignan

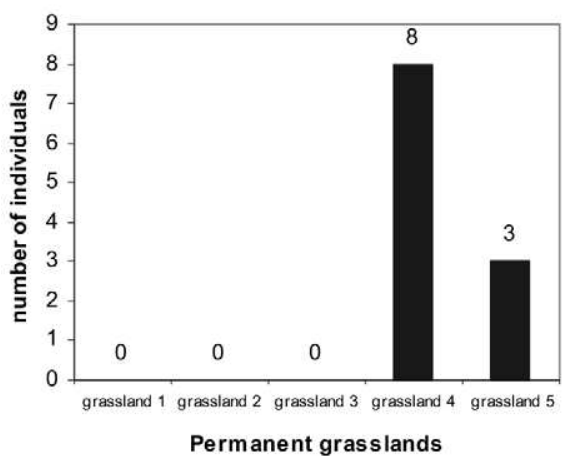

Fors

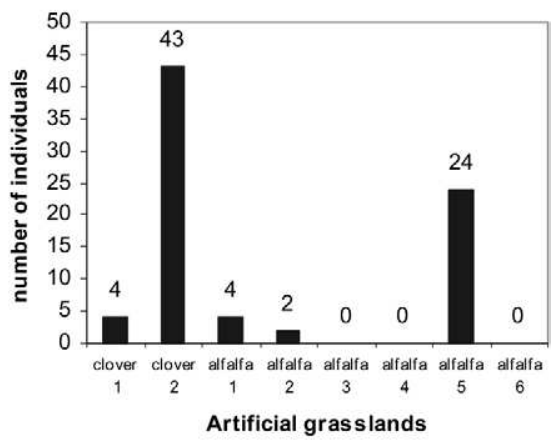

Fors

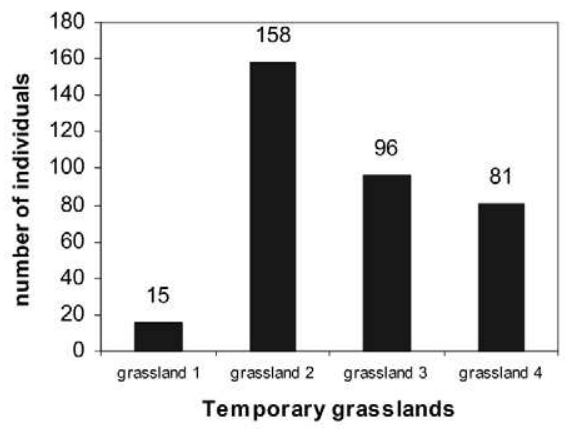

Fors

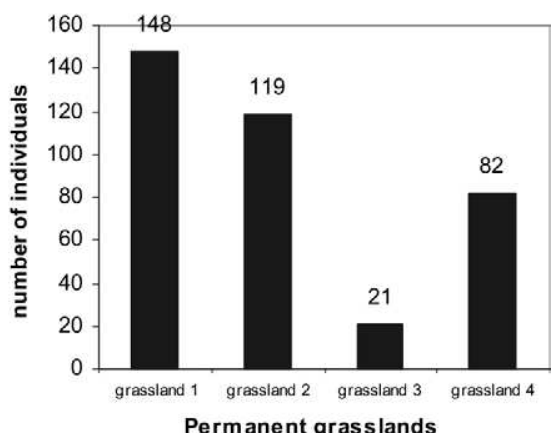

Fig. 2. Number of isopods collected in the different types of grasslands from Lusignan and Fors (per plot plus its borders). 
Table 4

Shannon diversity indices for each plot (plot, borders and connections), at the three sites

\begin{tabular}{lllll}
\hline & Alfalfa & Clover & $\begin{array}{l}<3 \text { year } \\
\text { grassland }\end{array}$ & $\begin{array}{l}>3 \text { year } \\
\text { grassland }\end{array}$ \\
\hline Lusignan & 0.64 & 0 & 0 & 0.52 \\
& 1.17 & & & 0.41 \\
& & & & 0.98 \\
& & & & 0.27 \\
Fors & 0.55 & 0.93 & 0.66 & 0.47 \\
& 0.59 & 0.22 & 0.52 & 0.49 \\
& 1.05 & & 1.09 & 0.92 \\
& 0.43 & & 1.01 & 0.18 \\
& 0.99 & & & \\
Avon & 0.67 & & & 0.92 \\
& & & & 1.05
\end{tabular}
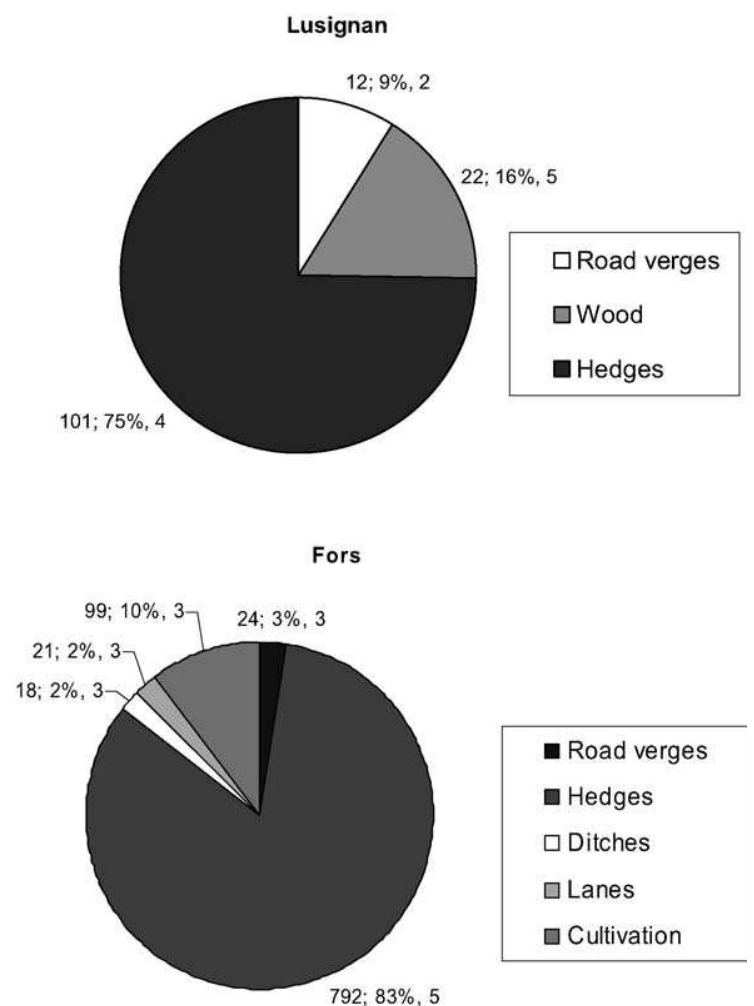

Fig. 3. Numbers of isopods, percentages, and number of species found in different types of connections at Lusignan and Fors.

large differences between two plots under the same culture regime. The difference in numbers seen in clover fields may be due to the fact that one had just been cut for silage. While artificial grassland samples were dominated by $P$. muscorum, they were less abundant in alfalfa (54\% of individuals). A. nasatum was the dominant species in temporary grasslands, $(53 \%$, com- pared to $30 \%$ for P. muscorum and $17 \%$ for $A$. vulgare). In permanent grasslands, $P$. muscorum was the most frequently encountered species, but $A$. nasatum and A. vulgare made up $33 \%$ and $24 \%$ of grassland samples, respectively.

At Avon, where grasslands were permanent, the densities of woodlice were higher than at Lusignan for the same type of grassland.

Four categories of connections (hedges, road verges, lanes and interfaces with other cultivation) were identified at both sites, although varying in number. For example, 16 hedges were encountered at Lusignan corresponding to 12 grassland plots and 36 at Fors for 16 plots. At Lusignan, wood and pond edges were distinctive connection type, as were ditches at Fors. Hedges harboured most individuals at both sites (Fig. 3). They contained individuals from four or five species depending on the site. The second most productive type of connection was wood and pond edges, found only at Lusignan. Other types of connection yielded fewer species. However, no isopods were found on tracks and cultivation interfaces at Lusignan.

Species were more often linked to site than to connection type. At Fors, three species (A. vulgare, $A$. nasatum, $P$. muscorum) were always found, irrespective of connection type. This association was complemented in hedges by the addition of $P$. scaber and $P$. cingendus. In hedges at Lusignan, four species were found ( $P$. muscorum, $O$. asellus, $P$. scaber and $P$. cingendus). The first three were also found in wood and pond edges, accompanied by $A$. vulgare and $A$. nasatum. Road verges contained two species, $P$. muscorum and P. cingendus, which were also present in hedges at Lusignan. The large number of woodlice in hedges (Fig. 3) influences the presence of individuals in the borders (representing 50 and $64 \%$ of individuals present in the hedges, at Lusignan and at Fors, respectively). Conversely, in connections between two types of crops, few individuals were encountered. Other connections (woods, road verges, ditches, tracks) also yielded few woodlice and influenced their presence in the borders less. The influence is reversed for cultivation connections, where fewer species were found in the border than in the connection. In such interactions of border and connection, both study sites behaved similarly.

\section{Discussion}

In the frame of an ongoing project we sampled calcareous semi-natural grasslands at Avon. In addition, improved pasture and meadows of different ages and 
different seed origins, from grass to clover and alfalfa, were sampled at Lusignan and Fors.

The structure of the landscape and its capacity to provide connections between habitats have been found to be important for isopods. The proximity of a suitable habitat for a permanent community of isopods will favour colonisation of new habitats. In our study, this influence is shown by the relationship between connections and plots, irrespective of site. Thus, hedges are the source of woodlice for grasslands. Therefore, the major species present in a plot occur also in the connections. Isopods are very influenced by variations in habitat structure [5], while the presence of some woodlouse species is linked with the degree of openness of the land, although some shrubs may be present, whereas other species are most common in closed habitats [4].

In exploited plots, vegetation structure and composition are not sufficient to explain differences between Lusignan and Fors, both in number of individuals and in species richness. Another possible factor is the mode of exploitation of the grasslands. Specific diversity and abundance of terrestrial isopods declines in intensive agricultural systems, with marked differences between plots farmed organically and those managed more conventionally [17]. The Lusignan site represents intensive practices continued over decades, while that at Fors is in a zone of mixed cultivation and stock rearing, although with some intensification in certain plots. P. muscorum is the dominant species at Lusignan, while at Fors and Avon, A. vulgare and A. nasatum are equally abundant. The latter two species are certainly more sensitive to agricultural practices. The differences between plots of the same type may be explained by differences in exploitation, as at Fors the studied plots belonged to different farmers. Cutting for silage is a major disturbance for all soil arthropods [3]. In Fors, one of the clover plots which had just been cut for silage yielded few individuals, although woodlice were present in the connections.

There may be recognisable guilds of woodlice species characteristic of natural grassland types [18]. In maritime grasslands $P$. muscorum, $A$. vulgare, E. purpurascens and P. scaber occurred, while in lowland grasslands the last two were replaced by T. pusillus, A. dentiger and P. cingendus [18]. The pattern for upland grasslands is not yet clear. Further investigations are needed to see if such guilds are found elsewhere, such as in Ireland, or in other natural grassland types, such as esker grassland or salt-marsh.

The nature and structure of the soil are also very important factors. For example, inputs of fertilisers will change the $\mathrm{pH}$ to a degree dependent on the nature of the soil. Isopods have also been shown to react to variations in $\mathrm{pH}$. A. vulgare is more sensitive than $P$. muscorum or P. scaber to acid $\mathrm{pH}$ and may be used as an indicator of acidification [20]. A. vulgare is very sensitive to $\mathrm{pH}$, with a preference for 7.0 [22]. This species is equally influenced by levels of soil calcium [25], but is fairly tolerant to dessication [8]. $P$. muscorum is less influenced by alkaline $\mathrm{pH}$ (preferring a level of 6.1 [22]). Conversely, it is sensitive to variations in temperature [25] and, as it cannot burrow in the soil, to low humidity [11]. O. asellus tolerates lower $\mathrm{pH}$, with a preference for 5.1 [22]. The abundance of isopods decreases 10 times faster than the level of $\mathrm{pH}$ [22]. These dips in $\mathrm{pH}$ can occur following the application of fertilisers, and particularly nitrogen [16]. Fertilisers are much used in rye-grass plots; in five plots of this type studied at Lusignan, no woodlice were found. In four of these plots, this may also be connected to the presence of cattle, which disturb woodlice by trampling and by elimination of litter [15].

Botanical composition, quality of plants and humidity are equally linked to soil type. However, soil data available at present for these sites are insufficient to evaluate such factors. Other, more general, factors also affect isopod communities. Climatic conditions (temperature, humidity) affect the number of individuals and their reproduction [13]. Also, the dominant species may change at different times of the year: populations of $P$. muscorum are highest in May, those of $P$. scaber in August, and A. vulgare in September. Despite these variations, while relative abundance may change, total isopod biomass remains constant [5]. Different species will react differently to environmental factors: competition pheromones are known to exist in isopods and affect the relationships between species. A large number of $P$. scaber in a habitat has a negative effect on growth of young A. vulgare, despite the fact that these species have well separated dates of hatching, so as to minimise competition [7].

Floristic composition is very important for arthropods, and particularly for terrestrial isopods. The Lusignan plots lacking isopods were temporary or permanent grasslands planted with rye-grass or cocksfoot grass, while woodlice were encountered in grasslands with a mixture of grasses and leguminous herbs. A. vulgare feeds preferentially on dicotyledonous plants such as legumes, rather than monocotyledonous (e.g. grasses) [19]. The age and quality of plants are also important in habitat choice [15]. In our study plots isopods were more numerous in grasslands at least 3 years old than in younger ones. Thus, at Lusignan a 3-yearold alfalfa plot contained many more isopods than a 1- 
year plot. Any cultivation that took place in the preceding year is also important for isopod populations. These may be in a colonisation phase, a phenomenon that will require a longer study to confirm. Further, isopods, being crustaceans, need a relatively damp environment and leguminous plants maintain soil humidity better than do grasses. Isopod diversity depends both on plant assemblages and on habitat humidity. Soil coverage will also help to retain moisture and to maintain a favourable habitat [21]. The alfalfa plots at Fors and cocksfoot at Lusignan had more than $10 \%$ bare soil. Exposed rocks would heat up in the sun, a factor that would tend to exclude woodlice. However, in Israel, as in other arid countries, terrestrial isopods were preferentially encountered under stones [10].

In conclusion, our results, from this preliminary study, suggest that certain woodlice species may be characteristic of various Atlantic grasslands, possibly due to their different habitat preferences $(\mathrm{pH}$, humidity etc.). These species may be useful as easily identified bioindicators of undisturbed, semi-natural conditions. Further research is in progress in order to compare these results with data obtained during other periods of the year.

\section{Acknowledgements}

Many thanks are due to Sylvia Reynolds (Dublin) and to Erick Rivault, Laurent Bruneteau and Jean-Pierre Frankowsky (Inra Lusignan) for their help in field investigations.

\section{References}

[1] T.G. Benton, S.P. Rushton, M. Hassall, J.E. Tuffon, R. A. Sanderson, Estimation of leaf litter production by dicotyledonous plants in grasslands, Eur. J. Soil Biol. 34 (1998) 11-24.

[2] E. Clere, V. Bretagnolle, Food availability for birds in the agricultural environment: biomass and diversity of arthropods captured by the pitfall method, Rev. Ecolo. 56 (2001) 275-292 (la Terre et la Vie).

[3] J.P. Curry, in: Grassland Invertebrates: ecology, Influence on Soil Fertility and Effects on Plant Growth, Chapman \& Hall, London, 1994, p. 437.

[4] J.-F. David, S. Devernay, G. Loucougaray, E. Le Floch, Belowground biodiversity in a Mediterranean landscape: relationships between saprophagous macroarthropod communities and vegetation structure, Biodivers. Conserv. 8 (1999) 753-767.

[5] R.C. Davis, Effect of weather and habitat structure on the population dynamics of isopods in a dune grassland, Oikos 42 (1984) 387-395.

[6] M. Hassall, Spatial variation in favourability of a grass heath as a habitat for woodlice (Isopoda: Oniscidea), Pedobiologia 40 (1996) 514-528 (Jena).
[7] M. Hassall, J.M. Dangerfield, Inter-specific competition and the relative abundance of grassland isopods, Monit. Zool. Ital. (NS), Monogr. 4 (1989) 379-397.

[8] M. Hassall, R.C. Davis, D. Procter, Lateral movements of isopods in a dune grassland, Proceedings of the Third European Congress of Entomology, Jenser G. (Ed.), 1992, pp. 733-739.

[9] M. Hassall, S.L. Sutton, The role of isopods as decomposers in a dune grassland ecosystem, Scientific Proceedings of the Royal Dublin Society, A6, 1978, pp. 235-245.

[10] E. Hornung, M.R. Warburg, Isopod distribution at different scaling levels, In: Crustacean Issues 9. Terrestrial Isopod Biology. Schram F.R. (Ed.), 1995, pp. 83-95.

[11] INRA, 2003. Etat des lieux de la Filière Fourrages, Document provisoire, 03 janvier 2002.

[12] P. Jambu, P. Juchault, J.P. Mocquard, Étude expérimentale de la contribution du crustacé isopode Oniscus asellus à la transformation des litières forestières sous chêne sessile, Pedobiologia 32 (1987) 147-156 (Jena).

[13] R.H. Miller, G.N. Cameron, Effect of temperature and rainfall on populations of Armadillidium vulgare in: Texas, Am. Midland Nat. 117 (1987) 192-198.

[14] J.P. Mocquard, P. Juchault, P. Jambu, E. Fustec, Essai d'évaluation du rôle des crustacés oniscoïdes dans la transformation des matières végétales dans une forêt feuillue de l'ouest de la France, Rev. Ecol. Biol. Sol. 24 (3) (1988) 311-327.

[15] M.G. Morris, Grassland management and invertebrate animals, a selective review, Scientific Proceedings of the Royal Dublin Society A6 (1978) 247-257.

[16] M.G. Paoletti, Using bioindicators based on biodiversity to assess landscape sustainability, Agric. Ecosyst. Environ. 74 (1999) 1-18.

[17] M.G. Paoletti, M. Hassall, Woodlice (Isopoda: Oniscidea): their potential for assessing sustainability and use as bioindicators, Agric. Ecosyst. Environ. 74 (1999) 157-165.

[18] J. Reynolds, M. Wickenberg, in: The distribution and diversity of woodlice (Crustacea, Isopoda) in grasslands of County Dublin, Ireland, and their potential as bioindicators, Report to Heritage Council, Ireland, 2002, p. 45.

[19] P. Rushton, M. Hassall, Food and feeding rates of the terrestrial isopod Armadillidium vulgare (Latreille), Oecologia 57 (1983) 257-261.

[20] F.X.S. Sastrodihardjo, N.M. Van Straalen, Behaviour of five isopod species in standardized test for $\mathrm{pH}$ preference, Eur. J. Soil Biol. 29 (1993) 127-131.

[21] K. Szlavecz, Diversity and spatial community structure of terrestrial isopods (Isopoda, Oniscidea) in a mosaic of plant assemblages, in: F.R. Schram (Ed.), Crustacean Issues 9, Terrestrial Isopod Biology, 1995, pp. 97-106.

[22] N.M. Van Straalen, H.A. Verhoef, The development of a bioindicator system for soil acidity based on arthropod $\mathrm{pH}$ preferences, J. Appl. Ecol. 34 (1997) 217-232.

[23] A. Vandel, Isopodes Terrestres (première partie), in: Faune de France, Lechevalier, Paris, 1960, pp. 1-416.

[24] A. Vandel, Isopodes Terrestres (deuxième partie), in: Faune de France, Lechevalier, Paris, 1962, pp. 417-931.

[25] M. Zimmer, H.J. Brauckmann, G. Broll, W. Topp, Correspondence analytical evaluation of factors that influence soil macroarthropod distribution in abandoned grassland, Pedobiologia 44 (2000) 695-704. 